\title{
Perception and Practice of Bangladeshi Adults Towards the Prevention of COVID-19: A Statistical Analysis
}

\author{
Md. Abdul Wadood ${ }^{1}$, Lai Lee Lee ${ }^{2}$, Md. Monimul Huq ${ }^{3}$, Asma Mamun $^{3}$, Suhaili Mohd ${ }^{2}$ and \\ Md. Golam Hossain ${ }^{3, *}$ \\ ${ }^{1}$ Medical Centre, University of Rajshahi, Rajshahi- 6205, Bangladesh \\ ${ }^{2}$ Department of Orthopedic Surgery (NOCERAL), Faculty of Medicine, University of Malaya, 50603 Kuala \\ Lumpur, Malaysia \\ ${ }^{3}$ Health Research Group, Department of Statistics, University of Rajshahi, Rajshahi-6205, Bangladesh
}

\begin{abstract}
Background: The coronavirus disease 2019 (COVID-19) has continued to spread across the world with increasing numbers of confirmed cases and deaths. Due to outbreaks of new variants of the virus and limited treatment options, positive perception and good practice of preventive guidelines have remained essential measures for the prevention of the disease and slowing down its transmission. We aimed to study perception towards COVID-19 and the practice of guidelines for preventing the disease among Bangladeshi adults during the early stage of the rapid rise of the outbreak.

Methods: Data was collected data from 320 participants. For measuring their level of practice, we asked a general question: "Are you properly following the WHO-recommended guidelines to avoid COVID-19?" The frequency distribution, Chi-square $\left(\mathrm{X}^{2}\right)$ test and binary logistic regression model were used in this study.

Results: The average risk perception among the participants was $3.05 \pm 0.75$ (median, 3.00$)(95 \% \mathrm{Cl}$ of mean: $2.96-3.13$ ) where the score ranges from 0 (no risk) to 4 (high risk). More than $27 \%$ of participants showed high-risk perceptions. Males $(p<0.05)$, high educated $(p<0.05)$, rich $(p<0.01)$, service holders $(p<0.05)$, and younger adults $(p<0.05)$ had higher odds of high-risk perception. More than $71 \%$ of participants had a good practice of always following the WHO guidelines to prevent COVID-19 and living locations in urban areas $(p<0.01)$, high education $(p<0.01)$, rich $(p<0.01)$, and joint family $(p<0.01)$ had the most contributions to good practice.
\end{abstract}

Conclusions: The study findings revealed that special attention should be given to rural areas, and individuals of low literacy, education and socioeconomic level to more effectively prevent COVID-19.

Keywords: COVID-19, Perception, Practice, Prevention, Bangladeshi adults, Logistic regression.

\section{BACKGROUND}

The coronavirus disease 2019 (COVID-19) is highly infectious with the main clinical symptoms of sore throat, fever, dry cough, difficulty breathing, myalgia, and fatigue [1]. Its causative agent, Severe Acute Respiratory Syndrome Coronavirus 2 (SARS-CoV-2), is a newly emerged zoonotic coronavirus that transmits from animal to human and human to human by the droplet and feco-oral route, and direct contact and has an incubation period of 2 to 14 days [2, 3]. It has been reported that $80 \%$ of people in high- and upper-middleincome countries have received the first dose of the vaccine while only $20 \%$ of people in low- and lowermiddle-income countries got their first dose of vaccine. The global picture of access to COVID-19 vaccines is unacceptable. However, COVAX has already achieved significant progress, it has been a commitment for up to 4.5 billion doses of vaccine; 240 million doses have been delivered to 139 countries in just six months $[1,4]$.

*Address correspondence to this author at the Professor of Health Research Group, Department of Statistics, University of Rajshahi, Rajshahi-6205, Bangladesh; E-mail: hossain95@yahoo.com
The COVID-19 outbroke first in the city of Wuhan in China in December 2019 [5]. Since then, it has continued to spread with an increase in the numbers of confirmed cases and death worldwide. The outbreak has appeared as the biggest disaster in the 21st century. The World Health Organization (WHO) declared it as a Public Health Emergency of International Concern on January 30, 2020 [6] and pandemic on 11 March 2020 [7]. The pandemic is still now out of control, and as of August 5, 2021, $200,193,983$ cases and 4,256,252 deaths were recorded worldwide [8].

A poor or lack of understanding about the transmission, control, and prevention of the disease may cause easy and rapid spread and delayed treatment of it. No specific and definitive antiviral treatment is available until now [1]. Protecting oneself from being exposed to COVID-19 is the easiest and effective measure of controlling the spread of the virus. This can be achieved by vaccination and following preventive guidelines. Although effective and safe COVID-19 vaccines are available, many countries like Bangladesh are facing difficulties in collecting and 
administering these vaccines and moreover, new variants of the virus are creating newer threats $[9,10]$. Re-infection of recovered patients and breakthrough infections of vaccinated people are also creating problems [11, 12]. Under these circumstances, people's knowledge, perception, attitude, and practice regarding the disease are the keys to ensuring success in the battle against the deadly disease. WHO prescribed some general guidelines for all sections of people to remain protected from COVID-19: (i) being well-informed about the mode of transmission and the signs and symptoms of the disease; (ii) washing hands frequently with soap for at least 20 seconds or disinfecting hands with sanitisers; (iii) avoiding touching of the face, nose, mouth, and eyes without washing or sanitizing hands properly; (iv) maintaining a social distance of at least one meter from one another; (v) staying home; (vi) avoiding crowds and gatherings; (vi) practicing respiratory etiquettes such as wearing masks, using handkerchiefs, tissue papers or flexed elbows to cover nose and mouth during coughing and sneezing, and so on [1]. In 2003, during the outbreak of SARS, knowledge and attitude toward the disease were found to be associated with panic and emotional breakdown among the population, which further complicated the control and prevention of the infection $[13,14]$.

Like many other countries in the world, Bangladesh is also trying to expand its controlling measures by imposing countrywide lockdowns and urging people to maintain the preventive guidelines of the WHO. Extensive campaigns in print, electronic, social, and other media by government and non-government organizations have supposedly increased the knowledge level about the causation, spread, control, and prevention of COVID-19 among the general population. The government has also started vaccination though at a slow pace. Despite all these measures, the pandemic has continued to flare up in the country due to mismanagement of the government bodies and the indifference of the general population. The numbers of cases of COVID-19 and deaths have continued to rise since the identification of the first confirmed case on March 8, 2020. As of August 5, 2021, 1,309,910 confirmed cases and 21,638 deaths were recorded in the country [15]. The situation demands studies on the perception and practice of preventive guidelines of the general population regarding the COVID-19 at different stages of the outbreak. To the best of our knowledge, there are very few published studies available until now on this issue.
One study has assessed the knowledge, attitude, practice, and perception toward COVID-19 among students in Bangladesh [16]. Another article studied the perception and knowledge towards COVID-19 among the Bangladeshi population [17]. The researchers conducted both studies in the early stage of the pandemic in Bangladesh.

We, therefore, aimed to study the perception towards COVID-19 and the practice of preventive guidelines among Bangladeshi adults during the early stage of the outbreak.

The study was based on the following two hypotheses:

$\mathbf{H}_{01}$ : Socio-economic factors are significantly associated with good practice of following the guidelines recommended by WHO to prevent COVID19.

$\mathbf{H}_{02}$ : Socio-economic factors are significantly associated with risk perception toward COVID-19.

\section{METHODS}

\section{Population and Sample}

A total number of 320 participants were selected from the Bangladeshi adult population for this crosssectional study. Data were collected from April 10 to April 20, 2020, through an online survey. Sex, different socioeconomic backgrounds and professions, and different living locations were considered while selecting samples.

\section{Sample Size Determination and Sampling}

We used the following formula to calculate the sample size $n=z^{2} p(1-p) / d^{2}$, where $n$ is the number of samples, $z$ is the value from the standard normal distribution for the selected confidence level (we considered $z=1.96$ for $95 \%$ confidence level), $p=$ the proportion of prevalence $=0.269(26.9 \%$ was the perception for getting COVID-19), $1-p=0.731$, and $d=$ the margin of error $=0.05$ (considered). This sample size information was taken from a previous study [18]. The mathematical formula provided that 297 samples would be sufficient for this study. However, data was collected from 320 samples.

Our four data collectors collected data from their acquaintances and friends and colleagues. They initially tried to contact 420 samples using their 
telephone numbers, but they were able to contact 402 and discussed our study. Among 402 adults, 351 agreed to provide their information.

\section{Questionnaire}

All necessary information of the respondents was collected using a self-developed questionnaire, which was designed according to the Survey Tool and Guidance (Rapid, simple, flexible behavioral insights on COVID-19) of WHO [19]. We took the suggestions of three infectious disease specialists before finalizing the questionnaire. The original English version of the questionnaire was then translated into Bangla (the mother tongue of Bangladesh) to make it easily understandable for the participants. We could not conduct a pilot survey for the shortage of budget and time. The Cronbach's Alpha value (0.792) revealed that the internal consistency (reliability) of the questionnaire was above the acceptance level (good).

\section{Data Collection Procedure}

Due to the ongoing lockdown, face to face interview was not possible. The questionnaire was distributed to the participants through online media like e-mail, messenger, and WhatsApp using personal computers, laptops, and cell phones. Four authors of the present study collected information from the participants, and the repetition of the responses was strictly checked. We sent the questionnaire to 351 participants but 320 of them responded with the completely filled-up questionnaire and written consent. The filled-up questionnaires were checked and found valid.

\section{Measurement of Perception and Practice}

The risk of perception was measured by four types of perceptions toward COVID-19 such as (i) seriousness of the disease; question: how serious do you think COVID-19 is?, (ii) susceptibility to the disease; question: what do you think about your chance of getting COVID-19?, (iii) efficacy and selfefficacy; question: do you think that you will manage to carry out prevention measures currently recommended by the authority?, (iii) intention to carry out the measures; question: are you willing to carry out prevention measures currently recommended by the authority? Four categorical scales were used to determine the risk perception level such as for perception (i) (a) very serious, (b) serious, (c) slightly serious and (d) not serious; for perception (ii) (a) very much chance, (b) much chance, (c) slightly chance and (d) no chance; for perception type (iii) and (iv) (a) most certainly, (b) probably yes, (c) probably not and (d) certainly not. Then (a) and (b) were considered as risk perception (code, 1), and (c) and (d) were indicated as (ii) no risk perception (code, 0 ) for each type of perception. The total perception score ranged from 0 (no risk) to 4 (high risk). We added all scores of four types of perception ((i) to (iv)) for calculating the actual level of total scores for measuring high-risk perception. A cut-off level of score $\leq 3$ (code, 0 ) was evaluated as low risk, and score 4 (code, 1) was indicated as high risk.

The practice of the WHO guidelines to avoid COVID-19 was measured using a general question based on WHO-recommended guidelines [1]. In the questionnaire, we asked the participants "Are you following COVID-19 prevention guidelines suggested by WHO?" The preventive guidelines were; (i) washing hands frequently with soap, (ii) wearing masks, (iii) maintain social distancing ( $>1$ meter), (iv) avoid group gathering, ( $v$ ) covering mouth and nose with a tissue or handkerchief when coughing or sneezing, and (vi) avoiding the touch of the mouth, nose, and eyes without washing hands with soap. Five measurement scales were used to understand the level of practice: (i) never, (ii) occasionally, (iii) sometimes, (iv) often, and (v) always. For further statistical analysis, samples were classified into two classes: (i) the participants answering "always" were considered as good practice (code, 1), and (ii) the participants answering other categorical scales (never to often), indicated as poor practice (code, 0 ).

\section{Outcome Variable}

There were two outcome variables for this study: (i) risk perception: (a) high risk perception (code, 1), and (b) low risk perception (code, 0); (ii) level of the practice: (a) good practice (code, 1), and (b) poor practice (code, 0 ).

\section{Independent Variables}

Some socioeconomic and demographic factors were considered as independent variables for examining the associations with good practice and high risk of perception toward COVID-19. Most of the socioeconomic and demographic factors were selected based on a related study [20]. These variables, their categories, codes, and definition are mentioned in Table 1. 
Table 1: Variables and their Categories with Codes and Definition

\begin{tabular}{|c|c|c|c|c|c|c|c|}
\hline Variable & Group & Definition & Code & Variable & Group & Definition & Code \\
\hline \multirow[t]{2}{*}{ Gender } & Male & & 1 & Residence & Urban & & 1 \\
\hline & Female & & 2 & & Rural & & 2 \\
\hline \multirow[t]{2}{*}{ Marital status } & Currently married & & 1 & Age group (year) & $<40$ & Young adult & 1 \\
\hline & Unmarried & & 2 & & $\geq 40$ & Adult & 2 \\
\hline \multirow[t]{4}{*}{ Education level } & $\begin{array}{l}\text { Uneducated or } \\
\text { primary }\end{array}$ & & 1 & Occupation & Service holder & & 1 \\
\hline & Secondary & & 2 & & Student & & 2 \\
\hline & Higher & & 3 & & Housewife & & 3 \\
\hline & & & & & Others & & 4 \\
\hline \multirow[t]{2}{*}{ Family member } & $\leq 4$ & Small family & 1 & $\begin{array}{l}\text { Family monthly } \\
\text { income (Taka) }\end{array}$ & $\leq 15000$ & Poor & 1 \\
\hline & $\geq 5$ & $\begin{array}{l}\text { Large } \\
\text { family }\end{array}$ & 2 & & $15001-30000$ & $\begin{array}{l}\text { Lower } \\
\text { middle }\end{array}$ & 2 \\
\hline \multirow[t]{2}{*}{ Type of family } & Nuclear & & 1 & & $30001-45000$ & $\begin{array}{l}\text { Upper } \\
\text { middle }\end{array}$ & 3 \\
\hline & Joint & & 2 & & $>45000$ & Rich & 4 \\
\hline
\end{tabular}

\section{Statistical Analysis}

Frequency distribution was used for determining the frequency with the percentage of samples corresponding to each question and level. Chi-square $\left(x^{2}\right)$ test was utilized to examine the association between (i) nature of practice and independent variables; (ii) risk of perception and independent variables. The binary logistic regression model was applied to assess the effect of demographic and socioeconomic factors on (i) nature of practice and (ii) risk of perception. Only significantly $(p<0.05)$ associated factors provided by $x^{2}$-test were used in the logistic model as independent variables.

The binary logistic regression model corresponding to variable used was:

$\log [p /(1-p)]=\beta x$

where $p$ is the probability of good practice (coded as $y=1$ ), $\beta$ is the vector of regression coefficients, and $x$ is the corresponding vector of independent variables. Similarly, the logistic regression model was used to model the second outcome, namely high risk of perception (coded as $y=1$ )."

We used SPSS (IBM Version 22.0) for statistical analysis. Statistical significance was accepted at $p<$ 0.05 .
RESULTS

\section{Baseline Characteristics}

The mean and median age of the participants was $40.99 \pm 14.99$ years (95\% Cl: 39.34-42.64) and 42.00 years respectively. The male and female participants were $64.4 \%$ and $35.6 \%$, whereas $60.0 \%$ and $40.0 \%$ of the participants came from urban and rural environments, respectively. Of the participants, $72.5 \%$ were currently married, $44.1 \%$ young adults (age $<40$ years), and $60 \%$ were highly educated. The majority of the participants $(78.1 \%)$ were living in nuclear families and $53.4 \%$ of the families were small (family member $\leq 4)$. More than $22 \%$ of the respondents were living in rich families (family monthly income $>45000$ Taka) while $29.4 \%$ living in poor families (income $\leq 15000$ Taka), and $32.8 \%$ of the participants were service holders (Table 2).

\section{Perception Towards COVID-19}

Of the respondents, a little more than $71 \%$ and $23 \%$ believed COVID-19 was a very serious and serious disease respectively. Only $9.7 \%$ of them believed they had very much chance to get COVID-19 while $31.6 \%$, $45.6 \%$, and $13.1 \%$ were supposed to have much chance, slight chance, and no chance of contracting the disease. About $72 \%$ of the participants said they would be able to maintain prevention measures 
Table 2: Association between Practice and Different Characteristics of Participants

\begin{tabular}{|c|c|c|c|}
\hline & & $\begin{array}{l}\text { Are you properly following the } \\
\text { guidelines recommended by WHO to } \\
\text { avoid COVID-19? }\end{array}$ & \\
\hline Variable & Group, N (\%) & Yes & p-value \\
\hline \multirow[t]{2}{*}{ Gender } & Male, $206(64.40)$ & $147(71.4)$ & \multirow[t]{2}{*}{0.954} \\
\hline & Female, $114(35.60)$ & $81(71.1)$ & \\
\hline \multirow[t]{2}{*}{ Residence } & Urban, $192(60.00)$ & $151(78.6)$ & \multirow[t]{2}{*}{$p<0.001$} \\
\hline & Rural,128 (40.00) & $77(60.2)$ & \\
\hline \multirow[t]{2}{*}{ Marital status } & Currently married, 232 (72.50) & $163(70.3)$ & \multirow[t]{2}{*}{0.525} \\
\hline & Unmarried, 88 (27.50) & $65(73.9)$ & \\
\hline \multirow[t]{2}{*}{ Age group (year) } & Young adult (age>40), 141 (44.1) & $105(74.5)$ & \multirow[t]{2}{*}{0.259} \\
\hline & Adult (age $\geq 40), 179$ (55.9) & $123(68.7)$ & \\
\hline \multirow[t]{3}{*}{ Education level } & Uneducated or primary, $53(16.6)$ & $26(49.1)$ & \multirow[t]{3}{*}{$p<0.001$} \\
\hline & Secondary, 73 (22.8) & $52(71.2)$ & \\
\hline & Higher, 194 (60.6) & $150(77.3)$ & \\
\hline \multirow[t]{2}{*}{ Family member } & Small ( $\leq 4), 171(53.40)$ & $114(66.7)$ & \multirow{2}{*}{0.052} \\
\hline & Large ( $\geq 5), 149(46.60)$ & $114(76.5)$ & \\
\hline \multirow{4}{*}{$\begin{array}{l}\text { Family monthly income } \\
\text { (Taka) }\end{array}$} & Poor ( $\leq 15000), 94(29.4)$ & $55(58.5)$ & \multirow{4}{*}{0.008} \\
\hline & Lower middle (15001-30000), 125 (39.1) & $92(73.6)$ & \\
\hline & Upper middle (30001-45000), 28 (8.8) & $22(78.6)$ & \\
\hline & Rich (>45000), 73 (22.8) & $59(80.8)$ & \\
\hline \multirow[t]{4}{*}{ Occupation } & Service holder, 105 (32.80) & $79(75.2)$ & \multirow{4}{*}{0.501} \\
\hline & Student, 66 (20.60) & $49(74.2)$ & \\
\hline & Housewife, 63 (19.70) & $42(66.7)$ & \\
\hline & Others, $86(26.90)$ & $58(67.4)$ & \\
\hline \multirow[t]{2}{*}{ Type of family } & Nuclear, 250 (78.10) & $169(67.6)$ & \multirow{2}{*}{0.006} \\
\hline & Joint, 70 (21.90) & $59(84.3)$ & \\
\hline
\end{tabular}

recommended by the authority. More than $96 \%$ of people had the intention to carry out prevention measures currently recommended by the authority (Table 3).

The average risk perception among the participants was $3.05 \pm 0.75$ (median, 3.00$)(95 \% \mathrm{Cl}$ of mean: 2.96 3.13). More than $51.5 \%$ of the respondents provided 3 risk perceptions followed by all (4) risk perceptions (27.8\%), 2 risk perceptions (18.4\%), 1 risk perception $(1.9 \%)$, and no risk perception $(0.3 \%)$ respectively (Table 4).

Chi-square test showed that gender $(p<0.05)$, age group (year) $(p<0.05)$, an education level $(p<0.05)$, family monthly income (Taka) $(p<0.01)$, and occupation $(p<0.01)$ were significantly associated factors of highrisk perception among Bangladeshi people (Table 5).
The effect of demographic and socio-economic factors on high-risk perception was described in Table 6. The statistical model demonstrated that males had 1.729-fold higher risk perception than females (OR=1.729, 95\% Cl: 1.01-2.96; $\mathrm{p}<0.05)$, and the high risk was diminished by $65.2 \%$ among lower educated (no or primary) adults compared to higher educated people $(\mathrm{OR}=0.348,95 \% \mathrm{Cl}$ : 0.149-0.816; $\mathrm{p}<0.05)$. High-risk perception was decreased by $73.4 \%$ among poor people compared to rich people in Bangladesh $(\mathrm{OR}=0.266,95 \% \mathrm{Cl}: 0.127-0.554 ; p<0.01)$. Housewife $(\mathrm{OR}=0.362,95 \% \mathrm{Cl}: 0.165-0.794 ; \mathrm{p}<0.05)$ and other professionals $\quad(\mathrm{OR}=0.472, \quad 95 \% \quad \mathrm{Cl}: 0.243-0.919$; $\mathrm{p}<0.05$ ) had low-risk perception towards COVID-19 than service holders respectively. The high-risk perception of young adults was 1.737 times higher than that of people aged $\geq 40$ years $(\mathrm{OR}=1.737,95 \% \mathrm{Cl}$ : 1.061-2.844; $p<0.05)($ Table 6). 
Table 3: Perception of Participants Toward COVID-19

\begin{tabular}{|c|c|c|c|c|c|}
\hline Type of perception & Questions & & & & \\
\hline $\begin{array}{l}\text { Perception of seriousness } \\
\text { of the disease }\end{array}$ & $\begin{array}{l}\text { How serious do you think } \\
\text { COVID-19 is? }\end{array}$ & $\begin{array}{l}\text { Very serious, } 229 \\
(71.6)\end{array}$ & $\begin{array}{l}\text { Serious, } \\
76(23.8)\end{array}$ & $\begin{array}{l}\text { Slightly serious, } \\
\qquad 15(4.7)\end{array}$ & $\begin{array}{l}\text { Not serious, } \\
0(0.0)\end{array}$ \\
\hline \multirow[t]{2}{*}{$\begin{array}{l}\text { Perception of susceptibility } \\
\text { to the disease }\end{array}$} & $\begin{array}{l}\text { What do you think about } \\
\text { your chance of getting } \\
\text { COVID-19? }\end{array}$ & $\begin{array}{l}\text { Very much chance, } \\
\qquad 31(9.7)\end{array}$ & $\begin{array}{l}\text { Much chance, } \\
101 \text { (31.6) }\end{array}$ & $\begin{array}{l}\text { Slight chance, } \\
146(45.6)\end{array}$ & $\begin{array}{c}\text { No chance, } 42 \\
(13.1)\end{array}$ \\
\hline & & Most certainly & Probably yes & Probably not & Certainly not \\
\hline $\begin{array}{c}\text { Perception of efficacy and } \\
\text { self-efficacy }\end{array}$ & $\begin{array}{l}\text { Do you think that you will } \\
\text { manage to carry out } \\
\text { prevention measures } \\
\text { currently recommended } \\
\text { by the authority? }\end{array}$ & $48(15.0)$ & $182(56.9)$ & $76(23.8)$ & $14(4.4)$ \\
\hline $\begin{array}{l}\text { Perception/Intention to } \\
\text { carry out the measures }\end{array}$ & $\begin{array}{l}\text { Are you willing to carry } \\
\text { out prevention measures } \\
\text { currently recommended } \\
\text { by the authority? }\end{array}$ & $243(75.9)$ & $65(20.3)$ & $12(3.8)$ & \\
\hline
\end{tabular}

Table 4: Level of Risk of Perception

\begin{tabular}{|c|c|c|c|}
\hline \multirow{2}{*}{$\begin{array}{l}\text { Mean } \pm S D=3.05 \pm 0.75 \\
\text { Number of questions }\end{array}$} & \multirow{2}{*}{$\begin{array}{c}\text { Median }=3.00 \\
\text { Risk of perception, } \mathrm{N}(\%)\end{array}$} & \multicolumn{2}{|c|}{$95 \% \mathrm{Cl}$ of mean: $2.96-3.13$} \\
\hline & & Number of questions & Risk of perception, N (\%) \\
\hline 0 & $1(0.3)$ & 3 & $165(51.6)$ \\
\hline 1 & $6(1.9)$ & 4 & $89(27.8)$ \\
\hline 2 & $59(18.4)$ & & \\
\hline
\end{tabular}

Table 5: Association between Perception Toward COVID-19 and Different Characteristics of Participants

\begin{tabular}{|c|c|c|c|c|}
\hline Variable & Group & \multicolumn{2}{|c|}{ Perception toward COVID-19 } & p-value \\
\hline Gender & Male & $141(68.4)$ & $65(31.6)$ & 0.045 \\
\hline \multirow[t]{2}{*}{ Residence } & Urban & $134(69.8)$ & $58(30.2)$ & \multirow[t]{2}{*}{0.241} \\
\hline & Rural & $97(75.8)$ & $31(24.2)$ & \\
\hline \multirow[t]{2}{*}{ Age group (year) } & Young adult $(>40)$ & $93(66.0)$ & $48(34.0)$ & \multirow[t]{2}{*}{0.027} \\
\hline & Adult $(\geq 40)$ & $138(77.1)$ & $41(22.9)$ & \\
\hline \multirow[t]{3}{*}{ Education level } & Uneducated or primary & $46(86.8)$ & $7(13.2)$ & \multirow[t]{3}{*}{0.034} \\
\hline & Secondary & $50(68.5)$ & $23(31.5)$ & \\
\hline & Higher & $135(69.6)$ & $59(30.4)$ & \\
\hline \multirow{3}{*}{$\begin{array}{l}\text { Family monthly income } \\
\text { (Taka) }\end{array}$} & Lower middle (15001-30000) & $87(69.6)$ & $38(30.4)$ & \multirow{3}{*}{0.004} \\
\hline & Upper middle (30001-45000) & $20(71.4)$ & $8(28.6)$ & \\
\hline & Rich $(>45000)$ & $44(60.3)$ & $29(39.7)$ & \\
\hline \multirow[t]{4}{*}{ Occupation } & Service holder & $69(65.7)$ & $36(34.3)$ & \multirow{4}{*}{0.003} \\
\hline & Student & $40(60.6)$ & $26(39.4)$ & \\
\hline & Housewife & $53(84.1)$ & $10(15.9)$ & \\
\hline & Others & $69(80.2)$ & $17(19.8)$ & \\
\hline \multirow[t]{2}{*}{ Type of family } & Nuclear & $183(73.2)$ & $67(26.8)$ & \multirow{2}{*}{0.445} \\
\hline & Joint & $48(68.6)$ & $22(31.4)$ & \\
\hline
\end{tabular}




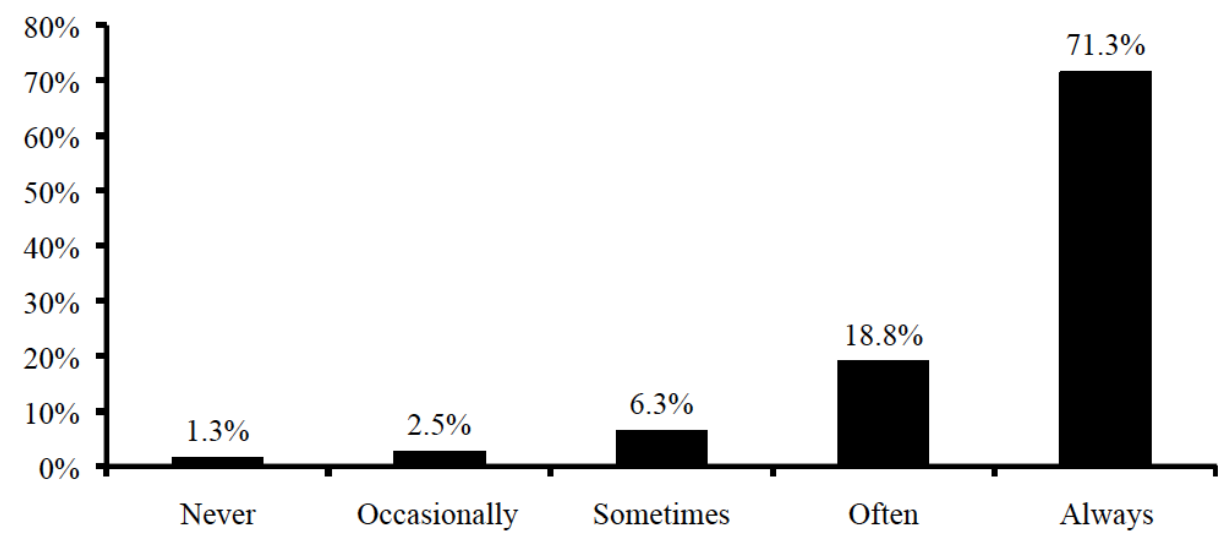

Figure 1: Level of practice to follow the guidelines recommended by WHO.

The Practice of Preventive Guidelines to Avoid COVID-19

The study revealed that $71.3 \%$ of the participants always followed the guidelines of $\mathrm{WHO}$ to prevent COVID-19 (Figure 1).

Chi-square test demonstrated that type of residence $(p<0.01)$, an education level $(p<0.01)$, family's monthly income $(p<0.01)$, type of family $(p<0.01)$, and a number of family members $(p=0.052)$ were significantly associated with the practice of preventive guidelines (Table 2). The logistic model revealed that the urban people had a 2.439-fold higher-good practice than rural people (OR=2.439, 95\% Cl: 1.488-3.999; $p<0.01)$. Good practice was decreased by $71.8 \%$ among uneducated or primary educated people compared to higher educated people (OR=0.282, 95\% Cl: 0.150 -

Table 6: Effect of Socio-Economic and Demographic Factors on Practice to Avoid and Perception Toward COVID-19 among Bangladeshi Adults

\begin{tabular}{|c|c|c|c|c|c|}
\hline \multicolumn{3}{|c|}{ Practice } & \multicolumn{3}{|c|}{ Perception } \\
\hline Covariates & OR (95\% Cl for OR) & $p$-value & Covariates & OR $(95 \% \mathrm{Cl}$ for OR) & p-value \\
\hline \multicolumn{3}{|l|}{ Residence } & \multicolumn{3}{|l|}{ Gender } \\
\hline Urban vs Rural & $2.439(1.488-3.999)$ & $p<0.001$ & Male vs Female & $1.729(1.01-2.96)$ & 0.046 \\
\hline \multicolumn{3}{|l|}{ Education Level } & \multicolumn{3}{|l|}{ Education Level } \\
\hline $\begin{array}{l}\text { Uneducated or } \\
\text { Primary vs Higher }\end{array}$ & $0.282(0.150-0.533)$ & $p<0.001$ & $\begin{array}{l}\text { Uneducated or } \\
\text { Primary vs Higher }\end{array}$ & $0.348(0.149-0.816)$ & 0.015 \\
\hline $\begin{array}{l}\text { Secondary vs } \\
\text { Higher }\end{array}$ & $0.726(0.395-1.334)$ & 0.303 & Secondary vs Higher & $1.053(0.589-1.882)$ & 0.863 \\
\hline \multicolumn{3}{|c|}{ Family Monthly Income (Taka) } & \multicolumn{3}{|c|}{ Family Monthly Income (Taka) } \\
\hline Poor vs Rich & $0.335(0.164-0.682)$ & 0.003 & Poor vs Rich & $0.266(.127-.554)$ & $p<0.001$ \\
\hline $\begin{array}{l}\text { Lower middle vs } \\
\text { Rich }\end{array}$ & $0.662(0.327-1.339)$ & 0.251 & $\begin{array}{l}\text { Lower middle vs } \\
\text { Rich }\end{array}$ & $0.663(.362-1.213)$ & 0.182 \\
\hline $\begin{array}{l}\text { Upper middle vs } \\
\text { Rich }\end{array}$ & $0.870(0.297-2.548)$ & 0.800 & $\begin{array}{l}\text { Upper middle vs } \\
\text { Rich }\end{array}$ & $0.607(0.236-1.561)$ & 0.300 \\
\hline \multicolumn{3}{|l|}{ Family member } & \multicolumn{3}{|l|}{ Occupation } \\
\hline $\begin{array}{l}\text { Small family vs } \\
\text { Large family }\end{array}$ & $0.614(0.374-1.007)$ & 0.053 & $\begin{array}{c}\text { Student vs Service } \\
\text { holder }\end{array}$ & $1.246(0.659-2.356)$ & 0.499 \\
\hline Type of family & & & $\begin{array}{l}\text { Housewife vs } \\
\text { Service holder }\end{array}$ & $0.362(0.165-0.794)$ & 0.011 \\
\hline \multirow[t]{3}{*}{ Nuclear vs Joint } & $0.389(0.194-0.780)$ & 0.008 & $\begin{array}{c}\text { Others vs Service } \\
\text { holder }\end{array}$ & $0.472(0.243-0.919)$ & 0.027 \\
\hline & & & \multicolumn{3}{|l|}{ Age Group } \\
\hline & & & $\begin{array}{l}\text { Young adults vs } \\
\text { Adults }\end{array}$ & $1.737(1.061-2.844)$ & 0.028 \\
\hline
\end{tabular}


0.533; $p<0.01)$. Poor participants showed less likeliness to follow WHO's guidelines properly (good practice) than rich ones (OR $=0.335,95 \% \mathrm{Cl}$ : $0.164-$ $0.682 ; p<0.01)$. Adults living in small $(\mathrm{OR}=0.614,95 \%$ $\mathrm{Cl}$ : $0.374-1.007 ; \quad \mathrm{p}=0.053)$ and nuclear families (OR=0.389, 95\% Cl: 0.194-0.780; $p<0.01$ ) showed less likeliness to having good practice than joint and large families respectively (Table 6).

\section{DISCUSSION}

COVID-19 has become a hot topic in all kinds of media and among people across the world including Bangladesh. Though the facts about the causation, transmission, control, treatment, and prevention of the disease are the same, perceptions and practices towards it differ in different countries due to differences in levels of socioeconomic status, demographic backgrounds, and measures taken by the governments. This demands specific studies for specific populations. To our knowledge, this study is the first attempt of this kind of research in Bangladesh.

The majority of the participants $(71.3 \%)$ in this study were practicing the guidelines of $\mathrm{WHO}$ to prevent COVID-19 though the level of practice is lower than that found in some other countries. A study conducted by Zhong et al. (2020) reported that about $98 \%$ of Chinese residents had an appropriate practice of measures for the prevention of COVID-19 [21]. Another study also reported a higher rate of practice (over 90\%) among the US people [22]. An Indian study found almost the same findings regarding the practice of preventive guidelines [23]. However, the level of good practice of our participants was found higher than that $(65.04 \%)$ of other populations such as the general population in Nigeria [24]. A study conducted in May 2020 found more than $90 \%$ of general people in Bangladesh had good practice of preventive measures [25]. Extensive campaigns about the higher rate of infectivity and fatality of the disease might make people conscious and careful about their health and life ultimately pushing them to practice preventive guidelines. Differences in patterns, trends, and levels of socioeconomic condition, religious beliefs, practices and culture, family and social bonding, population density, political culture, etc. might contribute to the different levels of practice in different countries. High education, living in urban areas, and high family income, the most contributory factors for the good practice among Bangladeshi people that we have found in this study are inter-related. These subgroups of people may be more knowledgeable, and more conscious about health and personal hygiene. This might help increase their practice of following the preventive measures to avoid COVID-19. The Chinese and US people with high socioeconomic status were found to have a higher percentage of good practice [21, 22]. A larger family is also helpful in acquiring knowledge and practicing preventive guidelines with discussion and exchange of views among the family members and correcting and inspiring one another. In our study, the urban people were reported to have a 2.439-fold higher-good practice than rural people. Higher educated participants are good in practice of prevention of COVID-19 compared to the uneducated or primary educated participants. Furthermore, also it was found that the participants from the poor community are less likely to follow WHO's guidelines properly than rich adults.

In our study, we also analyzed the individual perception towards COVID-19 regarding the severity of the disease, susceptibility to the disease, and selfefficacy and intention of the participants to carry out the preventive measures to avoid the disease. In this study, the associated demographic and socioeconomic factors of these perceptions were also identified. Near about two-thirds of the participants $(71.6 \%)$ were knowledgeable about the severity of the disease; more than $50 \%$ and $75 \%$ thought they had the capacity and will of continuing preventive measures respectively. Only $9.7 \%$ feared getting the infection certainly. All these findings reveal that the attitude, perception, and practice of the participants were more or less positive. Huge campaigns and publicity about the rapid spread of the disease, high death rates, and preventive measures might make them knowledgeable and conscious and have accurate perceptions towards the disease. These perceptions would hopefully help people take measures to avoid and prevent COVID-19. However, the perception of our respondents is not of the expected level. It is of a lower level compared to that of the Chinese [21] and Egyptian [26] people. An almost similar finding was found in a study conducted in Bangladesh [17]. The comparatively low level of positive perception among our respondents might be for their religious beliefs, moral insights, family cultures, and social customs. The high-risk perception of younger adults, males, high educated people, rich ones, and service holders might be explained by a hypothesis that these people of higher socioeconomic status are usually more conscious about their health and practice personal hygiene at a higher rate than their counterparts. Gender $(p<0.05)$, age group (year) 
$(p<0.05)$, an education level $(p<0.05)$, family monthly income (Taka) $(p<0.01)$, and occupation $(p<0.01)$ are found significantly associated factors of the high risk of perception among Bangladeshi people (Table 5).

This study revealed that $23.8 \%$ and $71.6 \%$ of respondents believed COVID-19 was a serious and very serious disease respectively. Only $9.7 \%$ of them believed they had very much chance to get COVID-19 while $31.6 \%, 45.6 \%$, and $13.1 \%$ were supposed to have much chance, slight chance, and no chance to get this disease. More than $50 \%$ of the participants would be able to manage to carry out prevention measures recommended by the authority and more than $75 \%$ of the people were willing to carry out prevention measures currently recommended by the authority (Table 3 ). Similar to many other countries, the government of Bangladesh is applying aggressive nontherapeutic measures for the prevention of the disease such as enforcing countrywide and regional lockdowns, banning travel on the road, water, rail, and air routes, etc. All kinds of educational institutions have remained closed since the outbreak. Most importantly, the practice of preventing measures such as social distancing, wearing face masks, and practicing hand hygiene are being encouraged to control the spread of COVID-19. The government also set up temporary quarantine sites for all travellers who entered the country and improve the healthcare facilities to minimize the impact of the COVID-19 pandemic [27].

The present study had several limitations. Firstly, the sample size of this convenience study cohort likely is not representative of the Bangladeshi population and this cohort's practice and perception may not generalize to the population. Another related limitation is the selection bias resulting from the convenience subject selection (from the acquaintances of the authors and their friends and colleagues). Secondly, data collected by the online survey were partly dependent on the participants' honesty and recalls ability; thus, they may be subject to recall bias. Thirdly, the study period was short, during a certain point of the peak of the pandemic in its early stage. The changes in practice and perception were not monitored. Fourthly, the population group of family monthly income $\leq 15000$ (Taka) was not explored enough. The low-income population might be uneducated or have low education levels due to low socioeconomic background and this might affect their practice and perception towards COVID-19. The socioeconomic factors were found to be significantly associated with practice and perception in this study. Fifthly, due to online survey, some other vulnerable populations such as un/low-educated people, older adults, adults with comorbid conditions, rural, and working people at the grass-root level could have not taken part in the study in sufficient numbers although they are more likely to have poor knowledge and perception, negative attitudes, and inappropriate preventive practices towards COVID-19.

\section{CONCLUSIONS AND RECOMMENDATIONS}

In summary, this study revealed that the Bangladeshi population with a high socioeconomic status had, though not up to the expected level, appropriate practices for the prevention of COVID-19 during the early stage of the outbreak. Also, risk perception about the disease was not up to the desired level. The findings suggest that proper health education programs are urgently needed to improve the perception of the people and maintain safe practices. In the face of the aggravating situation of the COVID-19 pandemic in Bangladesh, the government and nongovernment stakeholders should pay special attention to the vulnerable groups such as uneducated or low educated, aged, rural, and poor people. More studies are also warranted for investigating the knowledge, attitude, perception, and practice towards COVID-19 among the Bangladeshi population of low socioeconomic status.

\section{ABBREVIATIONS}

$\begin{array}{ll}\text { SARS-CoV-2 } & \text { Severe Acute Respiratory Syndrome } \\ & \text { Coronavirus } 2 \\ \mathrm{CI} & =\text { Confidence Interval } \\ \text { COVID-19 } & =\text { Coronavirus Disease } 2019 \\ \text { IBM } & =\text { International Business Machines } \\ \text { OR } & =\text { Odds Ratio } \\ \text { SARS } & =\text { Severe Acute Respiratory Syndrome } \\ \text { SPSS } & =\text { Statistical Package for the Social } \\ & \text { Sciences } \\ \text { WHO } & =\text { World Health Organization }\end{array}$

\section{ETHICS APPROVAL AND CONSENT TO PARTICIPATE}

The ethical clearance was obtained from the Ethical Committee, Institute of Biological Sciences (IBSc), Rajshahi University, Rajshahi-6205, Bangladesh to 
study infectious diseases. The written consent of every participant was taken and they sent it to us with the filled-up questionnaire.

\section{CONSENT FOR PUBLICATION}

Not applicable to this study.

\section{AVAILABILITY OF DATA AND MATERIAL}

Data will be available on request.

\section{COMPETING INTERESTS}

The authors have no conflict of interests.

\section{FUNDING}

There was no grant, technical or corporate support for this study.

\section{AUTHORS' CONTRIBUTIONS}

MAW, MGH, and LLL conceptualized and designed the study. MAW, MGH, MMH, and ASMM collected data. MAW, MGH, MMH, LLL, and SM interpreted data and findings. MAW, MGH, and LLL wrote the manuscript. All authors reviewed and approved the manuscript.

\section{ACKNOWLEDGEMENT}

We are indebted to those of our colleagues, friends, and relatives who helped us select and contact the respondents. We are also thankful to the respondents who took part in our survey.

\section{REFERENCES}

[1] WHO (2020). Corona Virus. https://www.who.int/healthtopics/coronavirus\#tab=tab_1. Accessed 27 March, 2020.

[2] Bhagavathula AS, Aldhaleei WA, Rahmani J, Mahabadi MA, Bandari DK. Novel Coronavirus (COVID-19) Knowledge and Perceptions: A Survey on Healthcare workers. Preprint at https://www.medrxiv.org/content/10.1101/2020.03.09.200333 $81 \mathrm{v} 2$

[3] World Health Organization. Novel Coronavirus (2019-nCoV): situation report, 13 (PDF) (Report).2020. https://experience.arcgis.com/experience/685d0ace521648f8 a5beeeee1b9125cd. Accessed 13 March 2020.

CDC (Centers for Disease Control and Prevention). Coronavirus Disease 2019 (COVID-19), Symptoms of Coronavirus. 2020. https://www.cdc.gov/coronavirus/2019ncov/symptoms-testing/symptoms.html. Accessed 3 May 2020.

[5] WHO. Novel Coronavirus (2019nCoV), Situation Report-1, 21 January 2020. https://www.who.int/docs/defaultsource/coronaviruse/situation-reports/20200121-sitrep-12019-ncov.pdf?sfvrsn=20a99c10_4. Accessed 3 May 2020.
WHO. Statement on the second meeting of the International Health Regulations (2005) Emergency Committee regarding the outbreak of novel coronavirus (2019-nCoV). 2020 https://www.who.int/news-room/detail/30-01-2020-statementon-the-second-meeting-of-the-international-healthregulations-(2005)-emergency-committee-regarding-theoutbreak-of-novel-coronavirus-(2019-ncov). Accessed 3 May 2020.

WHO. WHO Director-General's opening remarks at the media briefing on COVID-19-11 March 2020. 2020. https://www.who.int/dg/speeches/detail/who-director-generals-opening-remarks-at-the-media-briefing-on-covid-19---11march-2020. Accessed 3 May 2020.

CVRC (Corona Virus Resource Centre), John Hopkins University and Medicine. COVID-19 Dashboard by the Center for Systems Science and Engineering (CSSE) at Johns Hopkins University (JHU). 2020 https://coronavirus.jhu.edu/map.html. Accessed August 5, 2021.

[9] Ghosh B, Sarkar S, Sepay N, Das K, Das S, Dastidar SG Factors for COVID-19 Infection that Govern the Severity of Illness. SciMedicine Journal 2021; 3(2): 177-197. https://doi.org/10.28991/SciMedJ-2021-0302-9

[10] Tegally H, Wilkinson E, Giovanetti M, Iranzadeh A, Fonseca V, Giandhari J, de Oliveira T. Detection of a SARS-CoV-2 variant of concern in South Africa. Nature 2021; 592(7854): 438-443. https://doi.org/10.1038/s41586-021-03402-9

Tho Th, Hoang VT, Gautret P. Recurrence of SARS-CoV-2 viral RNA in recovered COVID-19 patients: a narrative review. European Journal of Clinical Microbiology \& Infectious Diseases 2020; 40(1): 13-25. https://doi.org/10.1007/s10096-020-04088-z

[12] Siegel M, Kloppenburg B, Woerle S, Sjoblom S, Danyluk G Notes from the Field: SARS-CoV-2 Transmission Associated with High School Football Team Members - Florida, September-October 2020. MMWR Morb Mortal Wkly Rep 2021; 70: 402-404

https://doi.org/10.15585/mmwr.mm7011a3

[13] Person B, Sy F, Holton K, Govert B, Liang A. National Center for Infectious Diseases SCOT. Fear and stigma: the epidemic within the SARS outbreak. Emerg Infect Dis 2004; 10: 35863 https://doi.org/10.3201/eid1002.030750

[14] Tao N. An analysis on reasons of SARS-induced psychological panic among students. Journal of Anhui Institute of Education 2003; 21: 78-9.

[15] IEDCR (Institute of Epidemiology, Disease Control and Research). Bangladesh Covid-19 Update. https://www.iedcr.gov.bd/. Accessed August 5, 2021.

[16] Wadood MA, Mamun ASMA, Rafi MA, Islam MK, Suhaili M Lai LL, Hossain MG. Knowledge, attitude, practice and perception regarding COVID-19 among students in Bangladesh: Survey in Rajshahi University. Preprint at medRxiv preprint. https://doi.org/10.1101/2020.04.21.20074757

[17] Farhana KM, Mannan KA. Knowledge and perception towards Novel Coronavirus (COVID 19) in Bangladesh International Research Journal of Business and Social Science 2020; 6(2): 76-79. https://doi.org/10.2139/ssrn.3578477

[18] Shabu S, Amen KM, Mahmood KI, Shabila NP. Risk perception and behavioral response to COVID-19 in Iraqi Kurdistan Region. BMC Infectious Diseases Pre-print. https://doi.org/10.21203/rs.3.rs-22025/v1

[19] WHO. Survey Tool and Guidance (Rapid, simple, flexible behavioural insights on COVID-19). 2020 http://www.euro.who.int/_data/assets/pdf_file/0007/436705/C OVID-19-survey-tool-and-guidance.pdf?ua $=1$. Accessed 3 May 2020. 
[20] Huynh TLD. Data for understanding the risk perception of COVID-19 from Vietnamese sample. Data Brief 2020; 30: 105530. https://doi.org/10.1016/j.dib.2020.105530

[21] Zhong BL, Luo W, Li HM, Zhang QQ, Liu XG, Li WT, Li Y. Knowledge, attitudes, and practices towards COVID-19 among Chinese residents during the rapid rise period of the COVID-19 outbreak: a quick online cross-sectional survey. International Journal of Biological Sciences 2020; 16(10): 1745.

https://doi.org/10.7150/ijbs.45221

[22] McFadden SM, Malik AA, Aguolu OG, Willebrand KS, Omer $\mathrm{SB}$. Perceptions of the adult US population regarding the novel coronavirus outbreak. PLoS ONE 2020; 15(4): e0231808. https://doi.org/10.1371/journal.pone.0231808

[23] Nazli T, Heena, Raheem A, Kishore J. Perceptions and Practices of the Adult Population in Response to SARS-CoV2 Pandemic in India. Epidem Int 2020; 5(2): 10-16. https://doi.org/10.24321/2455.7048.202011
[24] Habib MA, Dayyab FM, lliyasu G, Habib AG. Knowledge, attitude and practice survey of COVID-19 pandemic in Northern Nigeria. PloS One 2021; 16(1), e0245176. https://doi.org/10.1371/journal.pone.0245176

[25] Rahman MM, SJ Khan, Sakib MS, Halim MA, Rahman F, Rahman MM, Jhinuk JM, Nabila NH, Yeasmin MTM. COVID19 responses among general people of Bangladesh: Status and individual view toward COVID-19 during lockdown period. Cogent Psychology 2021; 8: 1. https://doi.org/10.1080/23311908.2020.1860186

[26] Abdelhafiz AS, Mohammed Z, Ibrahim ME, Ziady HH, Alorabi $M$, Ayyad M, Sultan EA. Knowledge, Perceptions, and Attitude of Egyptians Towards the Novel Coronavirus Disease (COVID-19). J Community Health 2020. https://doi.org/10.1007/s10900-020-00827-7

[27] Anwar S, Nasrullah M, Hosen MJ. COVID-19 and Bangladesh: Challenges and how to address them. Frontiers in Public Health 2020; 8 https://doi.org/10.3389/fpubh.2020.00154

https://doi.org/10.6000/1929-6029.2021.10.10

(C) 2021 Wadood et al.; Licensee Lifescience Global.

This is an open access article licensed under the terms of the Creative Commons Attribution License (http://creativecommons.org/licenses/by/4.0/) which permits unrestricted use, distribution and reproduction in any medium, provided the work is properly cited. 